\title{
RESPONSE OF GROWING JAPANESE QUAIL RAISED UNDER TWO STOCKING DENSITIES TO DIETARY PROTEIN AND ENERGY LEVELS
}

\author{
A.I. Attia, Kh.M. Mahrose, I.E. Ismail, and D.E. Abou-Kasem \\ Poultry Department, Faculty of Agriculture, Zagazig University, Zagazig, Egypt, Email: \\ ostrichkhalid@zu.edu.egor ostrichkhalid@hotmail.com
}

\section{SUMMARY}

The present study was performed to investigate the effect of dietary levels of protein and energy on growth performance and carcass traits of growing Japanese quail during 1-6 weeks of age under two stocking densities. A factorial design ( $2 \times 2 \times 3)$ arrangement was used included two stocking densities (12 birds or 24 birds in space of $40 \times 50 \mathrm{~cm})$, two levels of CP (22 and $24 \%)$ and three levels of energy (2800, 2900 and $3000 \mathrm{kcal} \mathrm{ME/} \mathrm{Kg).}$

The results of the present study showed that increasing stocking density of Japanese quails from 12 to 24 birds per $2000 \mathrm{~cm}^{2}$ led to a significant $(P \leq 0.01)$ reduction in live body weight at 3 and 6 weeks of age and body weight gain through 4-6 and 1-6 weeks of age. Live body weight at 3 weeks of age and live body weight gain during $1-3$ of age were significantly $(P \leq 0.01)$ maximized when chicks were fed $22 \%$ protein compared to those received 24\% protein. Live body weight at 3 and 6 weeks of age and live body weight gain through 1-3 and 1-6 weeks of age were significantly $(P \leq 0.01)$ decreased linearly with the increase in dietary energy from 2800 to $3000 \mathrm{kcal} \mathrm{ME} \mathrm{/} \mathrm{kg}$ diet. Interaction between stocking density and protein levels were significant $(P \leq 0.05)$ on live body weight at 3 weeks of age and body weight gain through the whole experimental period (1-6 weeks of age). Quail kept at $80 \mathrm{~cm}^{2}$ consumed $(P \leq 0.01)$ less feed as compared with those kept at $160 \mathrm{~cm}^{2}$ while, the best feed conversion ratio was obtained for birds kept at $160 \mathrm{~cm}^{2}$ than birds kept at $80 \mathrm{~cm}^{2}$. During 1-3 and 1-6 weeks of age, an improvement $(P \leq 0.05)$ in feed conversion was noticed with lower protein level $(22 \%)$. Increasing energy level in the quail grower diets from 2800 to 2900 and $3000 \mathrm{kcal} / \mathrm{ME} / \mathrm{kg}$ was associated with a significant $(P \leq 0.05$ or 0.01$)$ decrease in feed consumption and significant $(P \leq 0.01)$ improvement in feed conversion ratio during all the experimental periods studied. The present results did not show any significant effect on all studied carcass characteristics of growing Japanese quail due to stocking density, dietary protein and energy levels and their interaction, except giblets which was significantly $(P \leq 0.05)$ higher in chicks fed diets contained 2900 and $3000 \mathrm{kcal} \mathrm{ME} / \mathrm{kg}$.

Keyword:

\section{INTRODUCTION}

The influence of stocking density of different poultry species on growth and reproductive performance has generated a dearth of information on Japanese quail (Abdel- Hakim et al., 2005 and Abdel-Azeem, 2010). Intensive stocking density is one of the most effective stressors, especially during the final weeks of growing period (Askar and Assaf, 2004). Many investigators indicated that the high stocking density have been shown to induce poor conditions, reduction in growth rate, feed efficiency, livability and carcass quality (Puron et al., 1995; Fahmy et al., 2005; Seker et al., 2009 and El-Sagheer et al., 2012). Abdel-Azeem (2010) concluded that breeding of quail with a stocking density of $77 \mathrm{birds} / \mathrm{m}^{2}$ might yields better results when compared with quails stocked at $100 \mathrm{birds} / \mathrm{m}^{2}$ or those kept at 143 birds $/ \mathrm{m}^{2}$. However, there is a lack of information on the influence of stocking density on the performance of Japanese quail.
Protein source of high quality with adequate amino acid balance is one of the most important nutrients for quail. There are some differences in the nutritional requirements of quail as determined by various authors. Soares et al. (2003) evaluated five dietary crude protein levels $(16,18,20,22$ and $24 \%)$ in the rearing period of Japanese quail and concluded that protein levels had no effects on feed consumption and feed conversion ratio. They added that a crude protein requirement for rearing period of Japanese quail is $23.08 \%$.

The response of growing quails to dietary levels of essential amino acids, at different energy levels, on growth and immunity were investigated by Kaur et al. (2008). They concluded that the optimum level of dietary $\mathrm{ME}$ is $2700 \mathrm{kcal} / \mathrm{kg}$ with $25.83 \% \mathrm{CP}$ for optimum feed conversion during 0-5 weeks of age. Generally, the crude protein content in diets of growing quails ranges from 24 to $27 \%$ (NRC, 1994; Shrivastava and Panda, 1999; Baldini et al., 1995 and Mosaad and Iben, 2009). 
Therefore, the present study was performed to investigate the effect of dietary levels of protein and energy on the performance of growing Japanese quail under two stocking densities.

\section{MATERIALS AND METHODS}

The present study was carried out at the quail Research Farm, Poultry Department, Faculty of Agriculture, Zagazig University. Zagazig, Egypt.

A factorial design arrangement $(2 \times 2 \times 3)$ was performed included two stocking densities (12 birds or 24 birds in space of $40 \times 50 \mathrm{~cm}$ ), two levels of crude protein (22 and $24 \%$ ) and three levels of energy (2800, 2900 and 3000 $\mathrm{kcal} \mathrm{ME} / \mathrm{Kg}$ ) on growth performance and carcass traits of growing Japanese quail during 1-6 weeks of age. Therefore, a total number 648 of one week old Japanese quail were randomly assigned into 12 treatment groups, (36 chicks in each group of low stocking density and 72 chicks in each group of the high stocking density). Each group of birds was subdivided into three replicates, each of 12 chicks in the low stocking density and 24 chicks in the high stocking density. Each replicate was housed in one cage $(40 \times 50 \mathrm{~cm})$ either for the low or high stocking densities, respectively. The experimental diets (6 diets) were formulated to have two levels of crude protein (22 and 24\%) and three levels of energy (2800, 2900 and $3000 \mathrm{Kcal} \mathrm{ME} \mathrm{/} \mathrm{Kg).}$ Each experimental group in both low and high stocking density was fed one of the above mentioned diets (Table 1).

Quail chicks were grown in brooders with raised wire floors and were reared under the same managerial and hygienic conditions. The lighting pattern was $23 \mathrm{hr}$ light: $1 \mathrm{hr}$ dark. Feed and water were ad-libitum throughout the experimental period. Individual live body weight was recorded at 1,3 and 6 weeks of age; also body weight gain was calculated. Feed consumption data were recorded during the periods 1-3, 4-6 and 1-6 weeks of age on a replicate basis to estimate feed conversion.

At the end of growing period ( 6 weeks of age), five birds from each treatment were randomly taken with an average body weight around the treatment mean, fasted overnight, weighed and slaughtered by sharp knife to complete bleeding, then weighed, followed by plucking the feather and finally weight. The slaughter traits studied were giblets (liver, gizzard and heart), and dressing \% ((carcass weight plus giblets weight $) * 100$ / preslaughter g).

Data were statistically analyzed on a factorial design $(2 \times 2 \times 3)$ basis according to Snedecor and Cochran (1982) by adopting the following model:
$\mathrm{X}_{\mathrm{ijkl}}=\mu+\mathrm{D}_{\mathrm{i}}+\mathrm{P}_{\mathrm{j}}+\mathrm{G}_{\mathrm{k}}+\mathrm{DP}_{\mathrm{ij}}+\mathrm{DG}_{\mathrm{ik}}+$
$\mathrm{PG}_{\mathrm{jk}}+\mathrm{DPG}_{\mathrm{ijk}}+\mathrm{E}_{\mathrm{ijkl}}$,
where $\mathrm{X}_{\mathrm{ijk} \mathrm{l}}=$ any observation, $\mu=$ general mean, $D_{i}=$ fixed effect of $i^{\text {th }}$ stocking density (12 and 24), $P_{j}=$ fixed effect of $j^{\text {th }}$ level of crude protein ( 22 and $24 \%), \mathrm{G}_{\mathrm{k}}=$ fixed effect of $\mathrm{k}^{\text {th }}$ level of energy (2800, 2900 and $3000 \mathrm{kcal} \mathrm{ME} / \mathrm{Kg}$ ), $\mathrm{DP}_{\mathrm{ij}}=$ interaction between stocking density and crude protein levels, $\mathrm{DG}_{\mathrm{ik}}$ $=$ interaction between stocking density and energy levels, $\mathrm{PG}_{\mathrm{jk}}=$ interaction between crude protein levels and energy levels, $\mathrm{DPG}_{\mathrm{ijk}}=$ interaction among stocking density, crude protein levels and energy levels and $E_{\mathrm{ijkl}}=$ random error.

Differences among treatment means within the same factor were tested using Duncan's New Multiple Range test (Duncan, 1955).

\section{RESULTS AND DISCUSSIONS}

\section{Growth performance: \\ Live body weight and body weight gain: Stocking density effect:}

Results in Table 2 showed that, increasing stocking density of Japanese quails from 12 to 24 birds per $2000 \mathrm{~cm}^{2}\left(83 \mathrm{~cm}^{2}\right.$ per bird $)$ resulted in significant $(\mathrm{P} \leq 0.01)$ reduction in live body weight at 3 and 6 weeks of age and body weight gain during 4-6 and 1-6 weeks of age. This may be attributed to higher environmental temperature that occurred due to overcrowding. Overcrowding and less space per quail might cause stress on them. Also, in a high stocking density, the airflow at the level of the birds is often reduced resulting in reducing performance which include poor air quality due to inadequate air exchange, increased ammonia and reduced access to feed and water. Askar and Assaf (2004) attributed the unfavorable effects of high stocking density on live body weight and body weight gain of quail to the modification of the resting behavior due to the disturbances by the other birds.

Our results agreed with Fahmy et al. (2005) who observed that increasing stocking density of quail from 44, 88 and 176 birds/ $\mathrm{m}^{2}$ was associated with significant decrease in body weight. Al-Hanafy (2012) indicated that high stocking density $\left(125 \mathrm{~cm}^{2} /\right.$ bird $)$ significantly $(\mathrm{P} \leq 0.05$ or 0.01$)$ decreased body weight at 7 weeks of age and body weight gain during 3-6 and 1-6 weeks of age. Seker et al. (2009) showed that body gain was higher for quail stocked at 3 quail per $125 \mathrm{~cm}^{2}$ as compared with quail stocked at 10 quail per $125 \mathrm{~cm}^{2}$.

On the contrary, stocking density in Japanese quail did not significantly affect either body weight (Abdel-Hakim et al., 2005 and El-Sagheer et al., 2012) or body weight gain (Dhaliwal et al., 2008). 


\section{Protein level effect:}

Results in Table 2 indicated a significant effect $(\mathrm{P} \leq 0.01)$ on body weight at 3 and 6 weeks of age and body weight gain during 1-3, 4-6 and 1-6 weeks of age due to protein level effect. It could be noticed that, live body weight at 3 weeks of age and live body weight gain during 1-3 of age were higher when chicks were fed $22 \%$ protein compared to groups received $24 \%$ protein. However, with progress in age (from 4 to 6 weeks of age), live body weight at 6 weeks of age and live body weight gain through 3-6 weeks of age and during the whole experimental period (16 weeks of age) were significantly $(\mathrm{P} \leq 0.01)$ higher in chicks that received $24 \%$ crude protein. The positive effect of increasing protein level on growth performance may be due to increasing the amount of protein consumed.

Results of the current work are in agreement with those reported by Gheisari et al. (2011) who indicated that, increasing dietary protein in different stages of growth from very low, medium and high levels significantly $(\mathrm{P} \leq 0.05)$ increased body weight and body weight gain of growing Japanese quail. Also, Tarsewics et al. (2007) found that, quail fed diet containing very low protein level gave significantly lower body weight than those fed high protein diet.

Contradicting results were reported by Aboul-Ela et al. (2004) who showed that, the different protein levels $(22,24$ and $26 \%$ ) had no significant influence on live body weight and body weight gain during the growing period of Japanese quail.

\section{Energy level effect:}

Data in Table 2 showed that, live body weight at 3 and 6 weeks of age and live body weight gain during 1-3 and 1-6 weeks of age were significantly $(\mathrm{P} \leq 0.01)$ decreased linearly with the increase in dietary energy from 2800 to 2900 and $3000 \mathrm{Kcal} \mathrm{ME} / \mathrm{kg}$ diet.

These results agree with Aboul-Ela et al. (2004) who found that, Japanese quail chicks received 2800 and $2900 \mathrm{kcal} \mathrm{ME} / \mathrm{kg}$ diet up to 6 weeks of age were superior in live body weight than chicks received $3000 \mathrm{kcal} \mathrm{ME} / \mathrm{kg}$ by 4.31 and $2.55 \%$, respectively.

On the contrary, Gheisari et al. (2011) stated that, there were no significant effects of dietary ME levels (2700 or $2900 \mathrm{kcal} \mathrm{ME} / \mathrm{kg}$ ) on body weight and body weight gain.

\section{Interaction effects:}

Interaction between stocking density and protein levels were significant $(\mathrm{P} \leq 0.05)$ on live body weight at 3 weeks of age and body weight gain through the whole experimental period (1-6 weeks of age). The interaction between stocking density and energy levels were significant $(\mathrm{P} \leq 0.01)$ on live body weight at 6 weeks of age and body weight gain through 1-6 weeks of age.

The interaction between protein and energy levels were significant $(\mathrm{P} \leq 0.01)$ on live body weight at 3 weeks of age and body weight gain during 1-3 and 1-6 weeks of age.

The interactions between stocking density, energy level and protein level were significant $(\mathrm{P} \leq 0.01)$ on live body weight at 3 weeks of age and body weight gain during 4-6 and 1-6 weeks of age.

\section{Feed consumption and feed conversion: Stocking density effect:}

Results presented in Table 3 indicated that quail kept at $80 \mathrm{~cm}^{2} /$ bird consumed $(\mathrm{P} \leq 0.01)$ less feed as compared with those kept at 160 $\mathrm{cm}^{2} /$ bird. However, the best feed conversion ratio was obtained for birds kept at $160 \mathrm{~cm}^{2}$ than birds kept at $80 \mathrm{~cm}^{2}$. Feed consumption reduction may be due the reduction in floor space, which increases the competition for positions at the feeder trough. Al-Hanafy (2012) indicated that during all experimental periods (1-3, 4-6 and 1-6 weeks of age), high stocking density caused a significant improvement in feed conversion during 4-6 weeks of age.

However feed consumption was not significantly affected by stocking density during all the experimental periods. Seker et al. (2009) and Abdel-Azeem (2010) showed that the increasing in stocking density of Japanese quail resulted in a linear reduction in feed consumption. Al-Homidan and Robertoson (2007) indicated that increasing stocking density of Hybro broiler chicks from 10 to 15 birds $/ \mathrm{m}^{2}$ resulted in a reduction of feed consumption. However, they showed that feed conversion ratio was not significantly affected by increasing density from 10 to 15 bird $/ \mathrm{m}^{2}$

\section{Protein level effect:}

Results shown in Table 3 showed that, dietary protein concentration did not affect average feed consumption through 1-3 and 4-6 weeks of age. However, from 1-6 weeks of age, significantly $(\mathrm{P} \leq 0.01)$ higher feed consumption was observed for the group fed high protein level. These results are in agreement with the finding of Gheisari et al. (2011) who found that, the highest daily feed consumption $(\mathrm{P} \leq 0.05)$ was observed in the group feed high level of protein during the second rearing period (15-28 days). Siyadati et al. (2011) found that the birds fed on diets containing high crude protein $(27 \%)$ showed 
better feed conversion ratio than those fed other diets ( 24 or $21 \%$ ).

During 1-3 and 1-6 weeks of age, a significant $(\mathrm{P} \leq 0.05) \quad$ improvement in feed conversion was observed with lower protein level $(22 \%)$. However, protein level had no significant effect on feed conversion ratio during 4-6 weeks of age (Table 3).

The results of the present work are in agreement with those of Abou-Zeid et al. (2000), Abdel-Azeem et al. (2001) and AboulEla et al., (2004) who reported that feeding growing Japanese quail a diet contained high protein level (24\%) showed a remarkable improvement in body weight and feed conversion ratio as compared with quail received the lower protein level $(21 \% \mathrm{CP})$. Barque et al. (1994) found that the minimum feed consumption and better feed efficiency was noted in birds fed $26 \%$ protein diet.

\section{Energy level effect:}

Results in Table 3 showed that, increasing energy level in the quail grower diets from 2800 to $3000 \mathrm{kcal} / \mathrm{ME} / \mathrm{kg}$ was associated with a marked significant $(\mathrm{P} \leq 0.05$ or 0.01$)$ increase in feed consumption and significant $(\mathrm{P} \leq 0.01)$ improvement in feed conversion ratio during all the studied experimental periods. This means that during the starter and finisher periods, the lower energy feed was responsible for any increase in feed consumption. This may be explained on the basis that chicks require more dietary energy values covered by increasing feed consumption. However, birds have the ability to regulate their energy requirements by increasing feed consumption to certain extent.

These results are in good agreement with those reported by Gheisari et al. (2011) who reported that feed consumption of Japanese quail increased linearly with decreasing dietary energy level from 2900 to $2700 \mathrm{kcal} / \mathrm{ME} / \mathrm{kg}$. Kaur et al. (2008) reported that feed consumption of Japanese quail increased and feed conversion improved with decreasing dietary energy from 3100 to 2900 and 2700 $\mathrm{kcal} \mathrm{ME} / \mathrm{kg}$ during 0-3 or 0-5 weeks of age.

\section{Interaction effects:}

Results obtained in this study revealed that feed consumption was not significantly affected by the interaction between density $x$ protein, density $\times$ energy and density $\times$ protein $x$ energy during all the studied experimental periods (Table 3 ). However, feed consumption was significantly influenced $(\mathrm{P} \leq 0.01)$ by the interaction between protein $\times$ energy levels only at the periods from 1-3 and 4-6 weeks of age. These results agreed with Aboul-Ela et al. (2004) who revealed that feed consumption was not significantly affected by the interaction between protein $\times$ energy levels through all the studied experimental periods. Askar and Assaf (2004) clarified that the interaction effect between stocking density with protein level did not show and significance difference in feed consumption values of growing quail, while its effect was significant $(\mathrm{P} \leq 0.05)$ for feed conversion through 1-4 and 4-7 weeks of age.

Feed conversion values were significantly affected $(\mathrm{P} \leq 0.05$ or 0.01$)$ due to the interaction between density $\times$ energy during 4-6 and 1-6 weeks of age, density $\times$ energy during 1-6 weeks of age, protein $\times$ energy during all the experimental periods and between density $x$ protein $\times$ energy at the period from 3-6 and 1-6 weeks of age.

Aboul-Ela et al. (2004) found that feed consumption and feed conversion were not significantly affected by the interaction between protein and energy levels.

\section{Mortality rate (\%): \\ Stocking density effect:}

Results presented in Table 3 illustrated that mortality rate $(\%)$ recorded during all the experimental period of growing Japanese quail was significantly $(\mathrm{P} \leq 0.01)$ increased in those reared in the high stocking density as compared with the lower one. Mortality rate (\%) in this study indicated that overcrowding and space per quail might cause stress in quail and this led to increasing mortality rate.

These results are in agreement with those of Abdel-Hakim et al. (2005), Dhaliwal et al. (2008) and Abdel-Azeem (2010) who indicated that increasing stocking density of Japanese quail significantly increased mortality rate. On the other hand, Al-Hanafy (2012) indicated that mortality rate of growing Japanese quail was not significantly affected by stoking density.

\section{Protein level effect:}

Mortality rate (\%) of growing Japanese quail was not significantly affected by dietary protein level (Table 3). Similar results were obtained by Özek (2006) and Abdel-Mageed (2012). Tarasewicz et al. (2006) found that mortality rate was at similar level in Japanese quail fed diets contained 21, 19 and $17 \%$ crude protein.

\section{Energy level effect:}

Results in Table 3 showed that, increasing energy level in the quail grower diets from 2800 to $3000 \mathrm{kcal} / \mathrm{ME} / \mathrm{kg}$ was associated with a significant $(\mathrm{P} \leq 0.05$ or 0.01$)$ decrease in mortality rate $(\%)$.

Abdel-Hakim et al. (2009) stated that mortality percentage during the whole experimental period ranged between 5 to 7.50 $\%$. Almost all mortalities recorded in the 
present study were due to accidental factors during handing of birds and not to treatments.

\section{Interaction effects:}

Results shown in Table 3 indicated that mortality rate (\%) was significantly influenced $(\mathrm{P} \leq 0.01)$ by the interaction between the studied factors at all experimental period. Hassanein (2004) claimed that mortality rate during the period of $1-6$ weeks of age in quail was not significantly affected by either energy level, protein level or their interactions in winter or summer seasons.

\section{Carcass characteristics:}

Results in Table 4 did not show any significant effect on all studied carcass characteristics of growing Japanese quail due to stocking density, different dietary protein and energy levels or their interactions, except giblets which was significantly $(\mathrm{P} \leq 0.05)$ affected by energy levels. Giblets percentage was higher in chicks fed diets contained 2900 and $3000 \mathrm{kcal} \mathrm{ME} / \mathrm{kg}$ than those fed $2800 \mathrm{kcal}$ $\mathrm{ME} / \mathrm{kg}$.

Results of the present work are in agreement with those of Mizubuti et al. (2000) and Seker et al. (2009) who revealed that stocking density had no significant effect on slaughter and carcass characteristics. AboulEla et al. (2004) found that carcass traits (carcass, giblets and dressing percentages) were not affected due to either the different dietary energy and protein levels or their interactions. Mosaad and Iben (2009) concluded that the dressing percentage was significantly $(\mathrm{P} \leq 0.01)$ different due to the interaction of energy and protein levels. There was a linear increase of dressing $\%$ with the increase in crude protein and energy levels being highest in high protein and high energy diet. Siyadati et al. (2011) reported that quail fed diets containing low crude protein $(21 \%)$ gave lowest carcass yield than those fed higher protein diets (24 and 27\%).

In conclusion, the results of this study indicated that, low stocking density $\left(160 \mathrm{~cm}^{2}\right)$ was sufficient to give the best performance of Japanese quail. Taking body weight gain into consideration, the level of $22 \% \mathrm{CP}$ may be recommended till 3 weeks of age and $24 \%$ may be recommended from 4-6 weeks of age. Moreover, a level of $2800 \mathrm{kcal} \mathrm{ME} / \mathrm{kg}$ diet would be suitable from 1-6 weeks of age.

\section{REFERENCES}

Abdel-Azeem, F.A., 2010. The influence of different stocking density and sex on productive performance and some physiological traits of Japanese quail. Egyptian Journal of Poultry Science, 30 (1): 203-227.
Abdel-Azeem, F. Faten, A.A. Ibrahim and G.M. Nematallah, 2001. Growth performance and some blood parameters of growing Japanese quail as influenced by dietary different protein levels and microbial robotics supplementation. Egyptian Journal of Poultry Science, 21: 465-489.

Abdel- Hakim, N.F.; Abdel-Azeem, A, F.; ElShafiy, A. A. and Abdoullah, E. A. (2005). Effect of reserpine drug on performance of laying Japanese quail reared with two densities under hot climate. Egyptian Journal of Poultry Science, 25(II): 259277.

Abdel- Hakim, N.F.; Amer, A.A.; AbdelAzeem, A.F. and G. A. Abdel-Hafez (2009). Growth performance and nature of growth of Japanese quail as affected with dietary energy sources, levels and age under the Egyptian environmental condition. Egyptian Journal of Poultry Science, 29(III): 777 - 804.

Abdel-Mageed (2012). Effect of phase feeding of protein on Japanese quail performance. Egyptian Journal of Poultry Science, 32 (III): 661- 673.

Aboul- Ela, S. S.; El-Hindawy,M. M.; Attia, A. I. and Ashour, A. E. (2004). Protein and energy requirements of Japanese quail under Egyptian conditions 1- winter season. Zagazig Journal of Agricultural Researches, 31(3): 1045-1073.

Abou-Zeid, A. A.; Salwa Gaber; Semra Abou Egla and Zeweil, M.S. (2000). effect of dietary protein level and N- Fac 1000 supplementation on performance, digestibility and carcass in growing Japanese quail. Journal of Agricultural Sciences, Mansoura Uni., 25: 729-738.

Al-Hanafy, Laila, A. (2012). Effect of some feed additives on Japanese quail under hot climate. M. Sci Thesis. Fac. Agric., Zagazig Uni., Zagazig, Egypt.

Al-Homidan, A. and Robertson, J. F. (2007). The effect of stocking density and litter type on ammonia, dust, carbon dioxide concentration on broiler performance. Egyptian Journal of Poultry Science, Vol. 24(1): 37-51.

Askar, A.A. and Assaf, I.M.M. (2004). Biological performance of growing Japanese quail as affected by stocking density and dietary protein level. Journal of Agricultural Sciences, Mansoura Univ., 29(2): $623-638$.

Baldini, J.T.; Roberts, R.E. and Kirkpatrick, C.M. (1995). A study of the protein requirements of bobwhite quail reared in confinement in battery brooders to 8 weeks of age. Poultry Science, 29, 161-166. 
Barque, A.; Nawaz, H.; Ahmad, G. and Yaqoob, M. (1994). Effect of varying energy and protein levels on the performance of Japanese quails. Pakistan Journal of Agricultural Sciences, 31 (3): $224-227$.

Dhaliwal, A. P. S.; Nagra, S. S. and Brah, G. S. (2008). Effect of cage stocking density and season on laying performance of Japanese quail (Coturnix Coturnix Japonica). Indian Journal of Poultry Science, 24(3): 243-247.

Duncan, D. B. (1955). Multiple range and multiple F test. Biometrics, 11:1-42.

El-Sagheer, M.; El-Hammady, H.Y. and Farghly, M.F.A. (2012). Productive and Reproductive Performance of Japanese quail raised in batteries and on litter floor at two densities under the prevailing climatic conditions in Assiut Upper Egypt. $3^{\text {rd }}$ Mediterranean Poultry Summit and $6^{\text {th }}$ International Poultry Conference, 26 - 29 March 2012, Porto-Marina, Alexandria, Egypt, pp: $693-710$.

Fahmy, M. O.; Faramawy, A. A. and Gabr, S. A, (2005). Changes in blood parameters, reproductive and digestive system of Japanese quail as response to increased population density. Isotope and Radiation Research, 37(2), 287-298.

Gheisari, A.; Habib, A. H.; Ghasem, M.; Majid, T.; Amir, A. and Shahin, E. S. (2011). Effect of different dietary levels of energy and protein on performance of Japanese quails (Coturnix Coturnix Japonica). $2^{\text {nd }}$ International Conference on Agricultural and Animal Science, IPCBEE vol. 22. IACSIT Press, Singapore.

Hassanein, E.A.M. (2004). Some nutritional studies on quail. M.Sc. Thesis, Faculty of Agriculture, Zagazig University, Egypt.

Kaur, S. A.; Mandal, A. B.; Singh, K. B. and Kadam, M. M. (2008). The response of Japanese quails (heavy body weight line) to dietary energy levels and graded essensial amino acid levels on growth performance and immune-competence. Journal of livestock science, 117:255-262.

Mizubuti, I.Y; Mendes, A.R.; AzambujaRibeiro, E.L.; Rocha, M.A. and Camargo, D.S. (2000). Effect of different densities and feed restriction on carcass characteristics of broilers. Veterinaria Noticias, 2: 73 - 79 .

Mosaad, G.M.M. and Iben, C. (2009). Effect of dietary energy and protein levels on growth performance, carcass yield and some blood constituents of Japanese quails (Coturnix coturnix Japonica). Die Bodenkultur, 60(4): $39-46$.

National Research Council (1994). Nutrient Requirements of Poultry. $9^{\text {th }}$.rev. ed. Natl. Acad. Press, Washington, DC. (1994).

Özek, K. (2006). The Optimum Protein Content in High-Energy Starter Diet for Chukar Partridge (Alectoris chukar chukar). International Journal of Poultry Science, 5 (6): 522-525.

Puron, D.; Santamaria, R.; Segaura, J. C. and Alamilla, J. L. (1995). Broiler performance at different densities. Journal of Applied Poultry Research, 55-60.

Seker, I.; Selim, K. and Metin, B.A. (2009). Effect of group size on fattening performance, mortality rate, slaughter and carcass characteristics in Japanese quail (Coturnix Coturnix Japonica). Journal of Animal and Veterinary Advances, 8(4): 688-693.

Shrivastava, A. K. and Panda, B. (1999). A review of the nutrition on Japanese quail. World Poultry Science Journal, 55:73-81.

Siyadati,S.; Irani, M.; Ghazvinian, K.; MirzaeiAghsaghali, A.; Rezaipoor, V.; Fathi, H. Alipoor, K. and Zamanzad- Ghavidel, S. (2011). Effect of varying dietary energy to protein ratio on productive performance and carcass characteristics of Japanese quail. Annals of Biological Research, 2 (1):149-155.

Snedcor G.W. and Cochran W.G. (1982). Statistical Methods. 6th Edition, Lowa state University press, Ames, U.S.A.

Soares, R.; Fonseca, J. B.; Santos, A. S. and Mercandante, M. B. (2003). Protein requirement of Japanese quail (Coturnix Coturnix Japonica) during rearing and laying periods. Brazilian Journal of Poultry Science, 5:153-156.

Tarsewics, Z.; Gardzielewskaj, J.; Szczerbinska, D.; Ligocki, M.; Jakubowska, M. and Majewska, D. (2007). The effect of feeding with low protein feed mixes on the growth and slaughter value of young mail pharaoh quails. Archiv Tierzucht Dummerstorf, 50:1081-1084.

Tarsewics, Z.; Szczerbińska, D.; Ligocki, M.; Wiercińska,M. Jakubowska, M. and Romaniszyn, K. (2006). The effect of differentiated dietary protein level on the performance of breeder quails. Animal Science Papers and Reports, 24 (3): 207216 
Table 1. Composition and calculated analysis of the basal diets

\begin{tabular}{|c|c|c|c|c|c|c|}
\hline \multirow{2}{*}{ Ingredients } & \multicolumn{3}{|c|}{$22 \%$ Crude protein } & \multicolumn{3}{|c|}{ 24\% Crude protein } \\
\hline & $\begin{array}{c}2800 \\
\text { Kcal/kg }\end{array}$ & $\begin{array}{c}2900 \\
\text { Kcal/kg }\end{array}$ & $\begin{array}{c}3000 \\
\text { Kcal/kg }\end{array}$ & $\begin{array}{c}2800 \\
\mathrm{Kcal} / \mathrm{kg}\end{array}$ & $\begin{array}{c}2900 \\
\text { Kcal/kg }\end{array}$ & $\begin{array}{c}3000 \\
\mathrm{Kcal} / \mathrm{kg}\end{array}$ \\
\hline Yellow corn & 57.57 & 61.00 & 63.02 & 54.13 & 57.27 & 58.69 \\
\hline Soybean meal (44\%) & 28.00 & 29.50 & 23.10 & 30.10 & 30.10 & 24.60 \\
\hline $\begin{array}{l}\text { Corn gluten meal } \\
(60 \%)\end{array}$ & 4.00 & 5.00 & 7.00 & 5.50 & 6.00 & 10.00 \\
\hline Wheat bran & 5.00 & 0.00 & 0.00 & 4.00 & 0.00 & 0.00 \\
\hline Cotton seed oil & 0.00 & 0.00 & 0.35 & 0.00 & 0.40 & 0.40 \\
\hline Fish meal 72\% & 2.00 & 1.00 & 3.00 & 3.00 & 3.00 & 3.00 \\
\hline Limestone & 1.00 & 1.00 & 1.00 & 1.00 & 1.00 & 1.00 \\
\hline Vit. \& Min. premix ${ }^{(1)}$ & 0.30 & 0.30 & 0.30 & 0.30 & 0.30 & 0.30 \\
\hline $\mathrm{NaCl}$ & 0.30 & 0.30 & 0.30 & 0.30 & 0.30 & 0.30 \\
\hline Di-calcium Phosphate & 1.50 & 1.50 & 1.50 & 1.50 & 1.50 & 1.50 \\
\hline Dl- Methionine & 0.20 & 0.22 & 0.17 & 0.13 & 0.10 & 0.05 \\
\hline L-Lysine $\mathrm{HCl}$ & 0.13 & 0.18 & 0.26 & 0.04 & 0.03 & 0.16 \\
\hline Total & 100 & 100 & 100 & 100 & 100 & 100 \\
\hline \multicolumn{7}{|l|}{ Calculated analysis ${ }^{(2)}$} \\
\hline C.P \% & 22.13 & 22.05 & 22.08 & 24.15 & 24.04 & 23.95 \\
\hline $\mathrm{ME} \mathrm{kcal} / \mathrm{kg}$ & 2809 & 2911 & 3004 & 2805 & 2913 & 3007 \\
\hline $\mathrm{Ca} \%$ & 0.80 & 0.80 & 0.80 & 0.81 & 0.81 & 0.81 \\
\hline Avail. P \% & 0.46 & 0.46 & 0.46 & 0.47 & 0.47 & 0.47 \\
\hline Lysine \% & 1.31 & 1.33 & 1.35 & 1.31 & 1.31 & 1.30 \\
\hline Methionine \% & 0.42 & 0.43 & 0.43 & 0.43 & 0.43 & 0.42 \\
\hline Met.+ Cys. \% & 0.75 & 0.76 & 0.76 & 0.76 & 0.76 & 0.75 \\
\hline $\begin{array}{l}\text { (1) Growth vitamin and } \\
10 \mathrm{~g} ; \text { Vit } \mathrm{k}_{3} 2 \mathrm{~g} ; \mathrm{Vi} \\
20 \mathrm{~g} \text {, Folic acid , } \\
\mathrm{Si}, 100 \mathrm{mg} \text { and } \mathrm{Zn} \text {, }\end{array}$ & $\begin{array}{l}000 \mathrm{mg} \\
\mathrm{ng} ; \mathrm{Bio}\end{array}$ & $\begin{array}{l}\mathrm{h} 2.5 \mathrm{~kg} \\
\mathrm{~B}_{2}, 49 \mathrm{~g} \\
\mathrm{~g} ; \mathrm{Chol}\end{array}$ & $\begin{array}{l}\text { s of: Vi } \\
6,105 \mathrm{~g} \\
\text { oride, } 5\end{array}$ & $\begin{array}{l}00,000 \\
2,10 \mathrm{mg} \\
\mathrm{Fe}, 30 \mathrm{~g}\end{array}$ & $\begin{array}{l}\text { it } \mathrm{D}_{3}, 2000 \\
\text { tothenic ac } \\
40 \mathrm{~g} ; \mathrm{Cu} \text {, }\end{array}$ & $\begin{array}{l}\text { IU; Vit. E } \\
0 \mathrm{~g} \text {; Niacin } \\
\text { o, } 200 \mathrm{mg}\end{array}$ \\
\hline
\end{tabular}

Table 2. Live body weight and body weight gain of quail as affected by density, protein and energy levels and their interactions

\begin{tabular}{|c|c|c|c|c|c|c|}
\hline \multirow{3}{*}{ Treatments } & \multicolumn{3}{|c|}{ Live body weight (g) at } & \multicolumn{3}{|c|}{ Body weight gain (g) } \\
\hline & $\begin{array}{c}1^{\text {st }} \text { week of } \\
\text { age }\end{array}$ & $\begin{array}{c}3^{\text {rd }} \text { week of } \\
\text { age }\end{array}$ & $\begin{array}{c}6^{\text {th }} \text { week of } \\
\text { age }\end{array}$ & $\begin{array}{c}1-3 \\
\text { weeks }\end{array}$ & $\begin{array}{l}4-6 \\
\text { weeks }\end{array}$ & $\begin{array}{c}1-6 \\
\text { weeks }\end{array}$ \\
\hline & $\bar{X} \pm$ S.E. & $\bar{X} \pm$ S.E. & $\bar{X} \pm$ S.E. & $\bar{X} \pm$ S.E. & $\bar{X} \pm$ S.E. & $\bar{X} \pm$ S.E. \\
\hline $\begin{array}{l}\text { Density } \\
\text { levels: }\end{array}$ & NS & $* *$ & $* *$ & NS & $* *$ & $* *$ \\
\hline 12 & $30.46 \pm 0.25$ & $79.93^{\mathrm{a}} \pm 0.80$ & $183.71^{\mathrm{a}} \pm 1.36$ & $49.47 \pm 0.93$ & $103.78^{\mathrm{a}} \pm 1.63$ & $153.24^{\mathrm{a}} \pm 1.46$ \\
\hline 24 & $30.18 \pm 0.20$ & $76.06^{\mathrm{b}} \pm 1.08$ & $162.68^{\mathrm{b}} \pm 1.19$ & $45.88 \pm 1.15$ & $86.62^{\mathrm{b}} \pm 1.32$ & $132.50^{\mathrm{b}} \pm 1.24$ \\
\hline $\begin{array}{l}\text { Protein levels } \\
\% \text { : }\end{array}$ & NS & $* *$ & $* *$ & $* *$ & $* *$ & $* *$ \\
\hline 22 & $30.41 \pm 0.26$ & $79.51^{\mathrm{a}} \pm 1.08$ & $170.49^{\mathrm{b}} \pm 2.52$ & $49.10^{\mathrm{a}} \pm 1.20$ & $90.98^{\mathrm{b}} \pm 2.11$ & $140.08^{\mathrm{b}} \pm 2.50$ \\
\hline 24 & $30.24 \pm 0.19$ & $76.49^{\mathrm{b}} \pm 0.09$ & $175.90^{\mathrm{a}} \pm 3.01$ & $46.25^{\mathrm{b}} \pm 0.94$ & $99.42^{\mathrm{a}} \pm 2.55$ & $145.66^{\mathrm{a}} \pm 3.03$ \\
\hline $\begin{array}{l}\text { Energy levels } \\
\text { Kcal/kg: }\end{array}$ & NS & $* *$ & $* *$ & $* *$ & NS & $* *$ \\
\hline 2800 & $29.92 \pm 0.12$ & $80.90^{\mathrm{a}} \pm 1.07$ & $175.76^{\mathrm{a}} \pm 3.86$ & $50.98^{\mathrm{a}} \pm 1.10$ & $94.85 \pm 3.67$ & $145.84^{\mathrm{a}} \pm 3.90$ \\
\hline 2900 & $30.57 \pm 0.40$ & $77.93^{\mathrm{b}} \pm 1.31$ & $173.24^{\mathrm{b}} \pm 2.58$ & $47.36^{\mathrm{b}} \pm 1.44$ & $95.31 \pm 2.66$ & $142.66^{\mathrm{b}} \pm 2.47$ \\
\hline 3000 & $30.47 \pm 0.22$ & $75.16^{\mathrm{c}} \pm 0.91$ & $170.58^{\mathrm{c}} \pm 3.88$ & $44.68^{\mathrm{c}} \pm 0.91$ & $95.43 \pm 3.12$ & $140.11^{\mathrm{c}} \pm 3.88$ \\
\hline Interaction e & & & & & & \\
\hline $\begin{array}{l}\text { Density } \times \\
\text { Protein }\end{array}$ & NS & $*$ & NS & NS & NS & $* *$ \\
\hline $\begin{array}{l}\text { Density } \times \\
\text { Energy }\end{array}$ & NS & NS & $* *$ & NS & NS & $* *$ \\
\hline $\begin{array}{l}\text { Protein } x \\
\text { Energy }\end{array}$ & NS & $* *$ & NS & $* *$ & NS & $*$ \\
\hline $\begin{array}{l}\text { Density } \times \\
\text { Protein } \times \\
\text { Energy }\end{array}$ & NS & $* *$ & NS & NS & $* *$ & $* *$ \\
\hline
\end{tabular}


Table 3. Feed consumption and feed conversion of quail as affected by density, protein and energy levels and their interactions

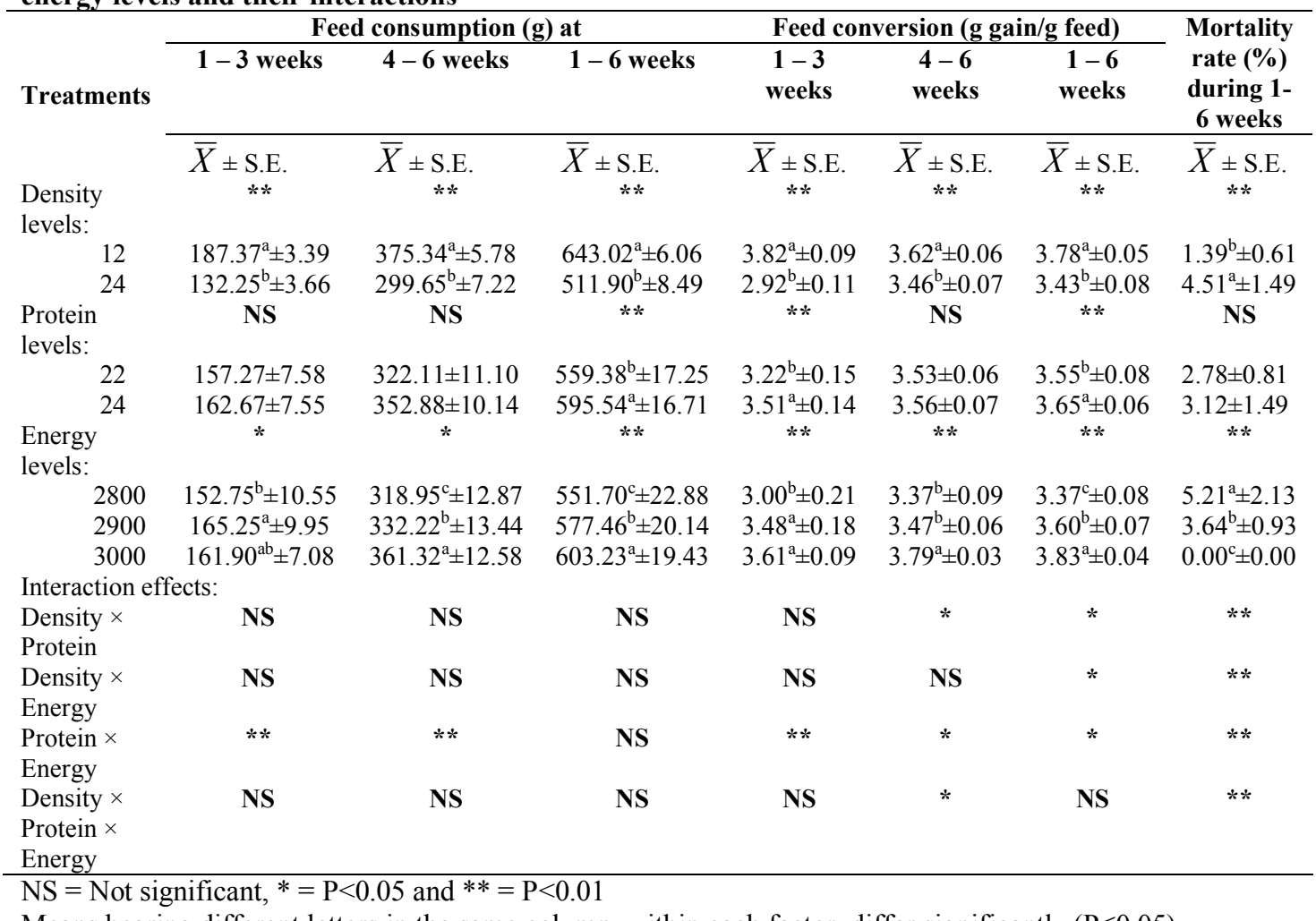

Means bearing different letters in the same column, within each factor, differ significantly $(\mathrm{P} \leq 0.05)$.

Table 4. Carcass traits of quail as affected by density, protein and energy levels and their interactions

\begin{tabular}{|c|c|c|c|c|}
\hline Treatments & $\begin{array}{c}\text { Pre-slaughter } \\
\text { weight } \%\end{array}$ & Carcass \% & Giblets \% & Dressing \% \\
\hline \multicolumn{5}{|l|}{ Density levels } \\
\hline $\mathrm{bird} / \mathrm{cm}$ : & NS & NS & NS & NS \\
\hline 12 & 146.44 & 70.35 & 5.55 & 75.90 \\
\hline 24 & 143.78 & 70.08 & 5.84 & 75.92 \\
\hline \multicolumn{5}{|l|}{ Protein } \\
\hline levels \%: & NS & NS & NS & NS \\
\hline 22 & 141.33 & 69.39 & 5.73 & 75.12 \\
\hline 24 & 148.89 & 71.04 & 5.66 & 76.70 \\
\hline \multicolumn{5}{|l|}{ Energy levels } \\
\hline Kcal/kg: & NS & NS & $*$ & NS \\
\hline 2800 & 147.17 & 69.88 & $5.08^{b}$ & 74.97 \\
\hline 2900 & 144.92 & 70.71 & $5.97^{\mathrm{a}}$ & 76.68 \\
\hline 3000 & 143.25 & 70.06 & $6.03^{\mathrm{a}}$ & 76.09 \\
\hline Density $\times$ & NS & NS & NS & NS \\
\hline \multicolumn{5}{|l|}{ Protein } \\
\hline Density $x$ & NS & NS & NS & NS \\
\hline \multicolumn{5}{|l|}{ Energy } \\
\hline Protein $\times$ Energy & NS & NS & NS & NS \\
\hline Density $\times$ & NS & NS & NS & NS \\
\hline Protein $\times$ Energy & & & & \\
\hline
\end{tabular}


إستجابة السمان الياباني النامي المربى تحت كثافتين للقطيع لمستويات البروتين و الطاقة في العليقة عادل إبراهيم عطية، خالد محمد محروس، إسماعيل السيد إسماعيل، ضياء السيد عراقي أبو القاسم قسم الدواجن، كلية الزراعة، جامعة الزقازيق، الزقازيق، مصر

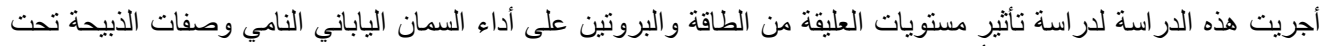

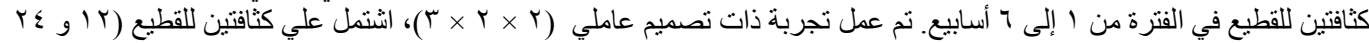

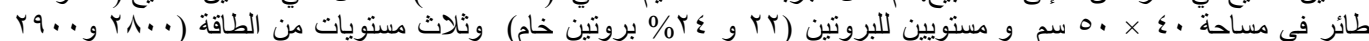

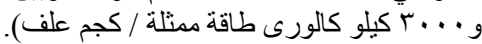

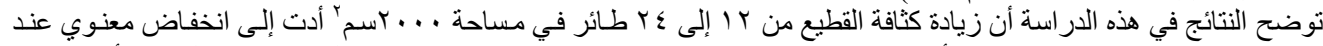

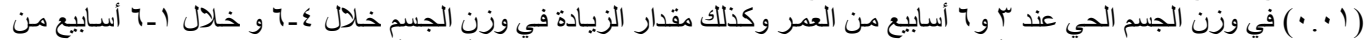

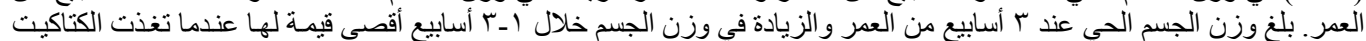

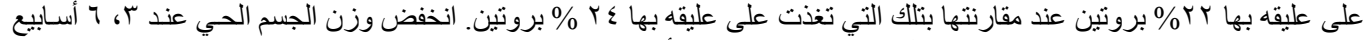

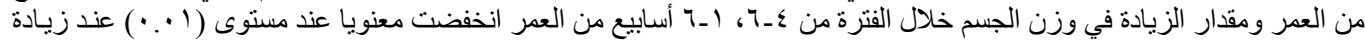

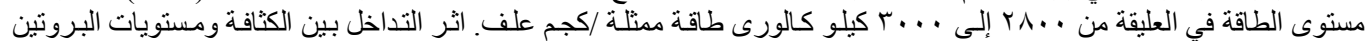

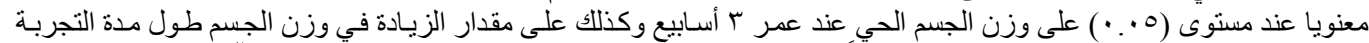

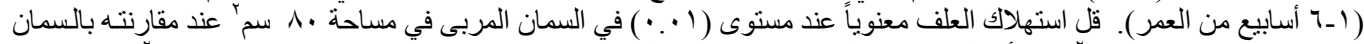

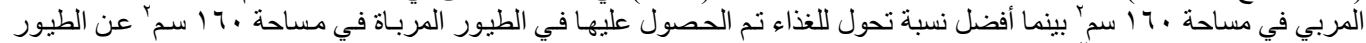

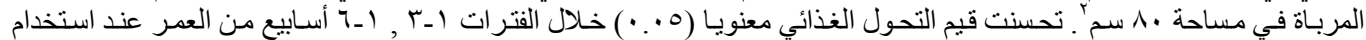

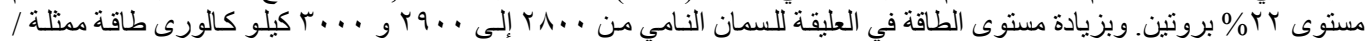

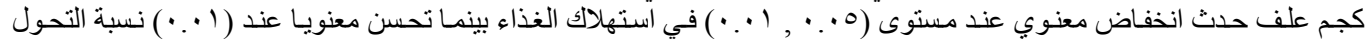

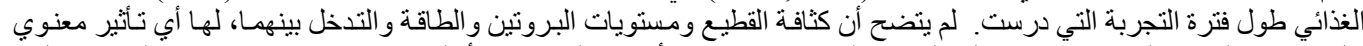

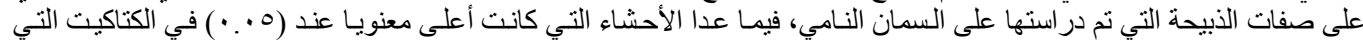

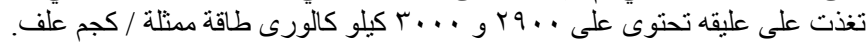

